\title{
СУСПIIЬHO-ГEOГРАФ/Ч/HI GOCIIOKEHHY
}

\author{
УДК 911.3:502.171 (477) \\ https://doi.org/10.15407/ugz2017.02.016

\begin{abstract}
С.А. Лісовський, Є.О. Маруняк, С.А. Покляцький, О.В. Горміз, Т.М. Чіпко
Інститут географрії Національної академії наук України, Київ
\end{abstract}

\section{СУСПІЛЬНО-ГЕОГРАФІЧНА ОЦІНКА ЗМІН У РЕГІОНАЛЬНОМУ ПРИРОДОКОРИСТУВАННІ УКРАЇНИ'}

\begin{abstract}
Узагальнено досвід суспільно-географічного дослідження змін в регіональному природокористуванні та оцінювання їх наслідків. Досліджено зміни в антропогенному навантаженні та структурі використання окремих компонентів природноресурсного потенціалу України. Досліджено сучасний стан та територіальні особливості природокористування в Україні на рівні АР Крим та адміністративних областей України, а також великих міст. Проведено оцінку економічних, соціальних та екологічних наслідків змін, що відбулися в регіональному природокористуванні в Україні. Сформульовано рекомендації щодо оптимізації регіонального природокористування для забезпечення збалансованого розвитку держави.
\end{abstract}

Ключові слова: Україна; регіональне природокористування; збалансований розвиток; якість життя; природноресурсний потенціал.

\section{S.A. Lisovskyi, Eu.O. Maruniak, S.A. Pokliatzkyi, O.V. Gormiz, T.M. Chipko}

Institute of Geography of the National Academy of Sciences of Ukraine, Kyiv

\section{SOCIO-GEOGRAPHICAL ASSESSMENT OF CHANGES IN REGIONAL NATURE MANAGEMENT OF UKRAINE}

The experience of social and geographical research of changes in regional environmental management and assessment of their effects has been summarized.

The changes of anthropogenic pressure as well as within the structure of Ukrainian natural-resource potential's use have been examined. Up-to-date state and territorial features of nature management in Ukraine at regional level as well as in major cities have been examined. The economic, social and environmental consequences of the changes in the regional nature management in Ukraine have been evaluated. Recommendations on how to optimize regional nature use to ensure balanced development of the state have been delivered.

Keywords: Ukraine; regional nature use; sustainable development; quality of life; natural-resources potential.

Актуальність теми дослідження

Є кілька підходів до визначення поняття «природокористування» за різними ознаками: за окремими видами (промислове, сільськогосподарське, рекреаційне тощо), характером використання природних ресурсів (землекористування, водокористування, лісокористування, використання мінеральних ресурсів та інші), за функціями (сукупність усіх форм використання природно-ресурсного потенціалу і засобів його збереження) та інші.

На думку академіка Л.Г. Руденка, під природокористуванням слід розуміти відношення людини і суспільства до компонентів природи, яке розкривається в особливостях використання окремих видів ресурсів з метою забезпечення життєдіяльності людей, грунтується на оцінках екологічної ємності території та діях щодо збереження природних властивостей компонентів природи, ландшафтного та біорізноманіття [1].

${ }^{1}$ Статтю підготовлено за матеріалами НДР «Суспільногеографічна оцінка змін у регіональному природокористуванні України» (Лісовський С.А., Гукалова I.В., Дронова О.Л., Маруняк Є.О., Мозговий А.А., Михайлик Л.П., Покляцький С.А., Чемерис С.Л., Горміз О.В., Торушанко В.Р., Чіпко Т.М.)
У 90-х роках ХХ ст. Україна посідала одне 3 перших місць у світі за рівнем споживання енергії, води та інших ресурсів на одиницю ВВП. Значні та різноманітні природні ресурси країни протягом тривалого історичного періоду зазнавали масштабної екстенсивної експлуатації, що призвело до їх значного вичерпання та деградації.

Проблеми природокористування в Україні та iii регіонах виникли давно, ще за часів СРСР та перебування території країни в складі різних імперій. Природно-ресурсний потенціал (ПРП) використовувався для задоволення, передусім, інтересів метрополій, а не потреб України. Переважно внаслідок цього багато його компонентів зазнали виснаження й забруднення. Здобуття Україною незалежності давало надії на докорінне покращення ситуації. Однак, процес реформування економіки України протягом 90-х років, що розпочався в умовах глибокої системної кризи, посилив гостроту старих і породив низку нових проблем природокористування. 3 часу становлення України, як незалежної держави, та початку реформ у країні, за період з 1991 р. кардинально змінилися:

- масштаби використання природних ресурсів у регіонах та за окремими видами економічної діяль- 
ності (галузями);

- система управління використанням ресурсів;

- порядок плати за ресурси та система цін на їх окремі компоненти;

- можливості доступу до окремих компонентів природних ресурсів;

- інституційні засади управління ресурсокористуванням; їни.

- структура зовнішньоекономічних зв'язків кра-

Окрім того, Україна приєдналася до багатьох міжнародних угод, які регулюють питання ресурсокористування, охорони окремих компонентів ПРП, реалізує низку реформ, насамперед 3 децентралізації влади. Негативний вплив на характер природокористування мали наслідки анексії Криму та агресія Росії на Донбасі.

М е т а публікації - оцінка та аналіз суспільно-географічних змін у регіональному природокористуванні, їх соціально-економічних та екологічних наслідків та розробка суспільно-географічних рекомендацій щодо оптимізації регіонального природокористування в Україні.

\section{Стан вивчення, основні праці}

Для України, в межах території якої накопичилась значна кількість проблем суспільно-природної взаємодії, питання оптимізації природокористування мають надзвичайно важливе значення. У дослідженні проблематики природокористування, у тому числі питань регіонального природокористування, в Україні використовували і розвивали досягнення зарубіжних вчених, зокрема колег з колишніх республік СРСР.

У Секторі, Відділенні, нині Інституті географії НАН України основні теоретичні та методичні питання регіонального природокористування опрацьовані М.М. Паламарчуком, О.М. Мариничем, Л.Г.Руденком, М.Ф.Векличем, В.І. Галицьким, А.П.Золовським, І.О.Горленко, В.П. Палієнко, В.М.Пащенком, С.А. Лісовським, Г.О.Пархоменко та іншими науковцями. В окремих виданнях викладено методологічні й теоретичні основи досліджень природокористування [3, 4], концепції нового напряму тематичного картографування [2]. Розширюючи коло досліджень регіонального природокористування, географи вже тривалий час здійснюють розробки з проблематики сталого (збалансованого) розвитку. Ці дослідження відомі в українській академічній географії ще до Конференції ООН з навколишнього середовища і розвитку «Ріо 92», зокрема за працею «Сбалансированное экономическое, социальное и экологическое развитие территории (экономико-географические аспекты)» [9].

Географи були в числі авторів перших публікацій, в яких опрацьовано питання впровадження в Україні рішень Саміту в Pio $[7,10]$. В Інституті географії 2012 р. було підготовлено «Проект до- повіді України до конференції ООН зі сталого (збалансованого) розвитку «Ріо + 20» [8]. У 2014 р. видано підготовлену в Інституті географії на замовлення Міністерства екології та природних ресурсів України, у співпраці з іншими установами НАН України та громадськими організаціями національну доповідь «Стан виконання в Україні положень «Порядку денного на XXI століття (20022012)» [11]. Зазначимо, що результати суспільногеографічних досліджень проблем регіонального природокористування $\epsilon$ важливою складовою наукового забезпечення практичної реалізації в Україні принципів основної парадигми XXI століття.

\section{Виклад основного матеріалу}

Основні риси природокористування, що визначали його характер впродовж всього періоду перебування України в складі СРСР, були закладені у другій половині XIX ст., ще за часів Російської імперії. У цей період українські землі, окрім традиційного статусу «житниці імперії», стали основною базою важкої промисловості Росії. Зазначена спеціалізація зберігалась і у радянський період. Природні ресурси України використовувалися для потреб усього СРСР, а природокористування в межах іiі території мало ресурсоємний характер, це призводило до значних негативних наслідків для стану компонентів довкілля, що грунтовно проаналізовано в [12]. Отже, на стартових позиціях 3 часу здобуття незалежності українська економіка мала чітко виражений екстенсивний характер природокористування з надмірними показниками сільськогосподарської освоєності території, значним розвитком гірничо-добувної промисловості, чорної металургії, хімії, інших природоємних видів економічної діяльності.

Основними еколого-економічними проблемами, зумовленими особливостями такої структури, для України були і залишаються: загальний високий ступінь антропогенної зміненості території; надвисокий рівень сільськогосподарської освоєності, насамперед - розораності; зумовлене цим порушення пропорцій у співвідношенні ріллі, луків та лісових площ; невисокий рівень лісистості, значна частка техногенно змінених земель; наявність великих площ порушених угідь, що потребують рекультивації; низький відсоток земель, на яких встановлений природно-заповідний режим; вкрай незначна кількість територій, що зберегли свій первісний природний стан; поширення на землях сільськогосподарського використання таких негативних процесів як ерозія, дефляція, підтоплення, заболочення, засолення тощо. На початку 90-х рр. $\mathrm{XX}$ ст. еколого-економічні показники економіки України були одними з найгірших у світі.

3 часу набуття незалежності України радикальних змін потребувала вся система законодавства, 


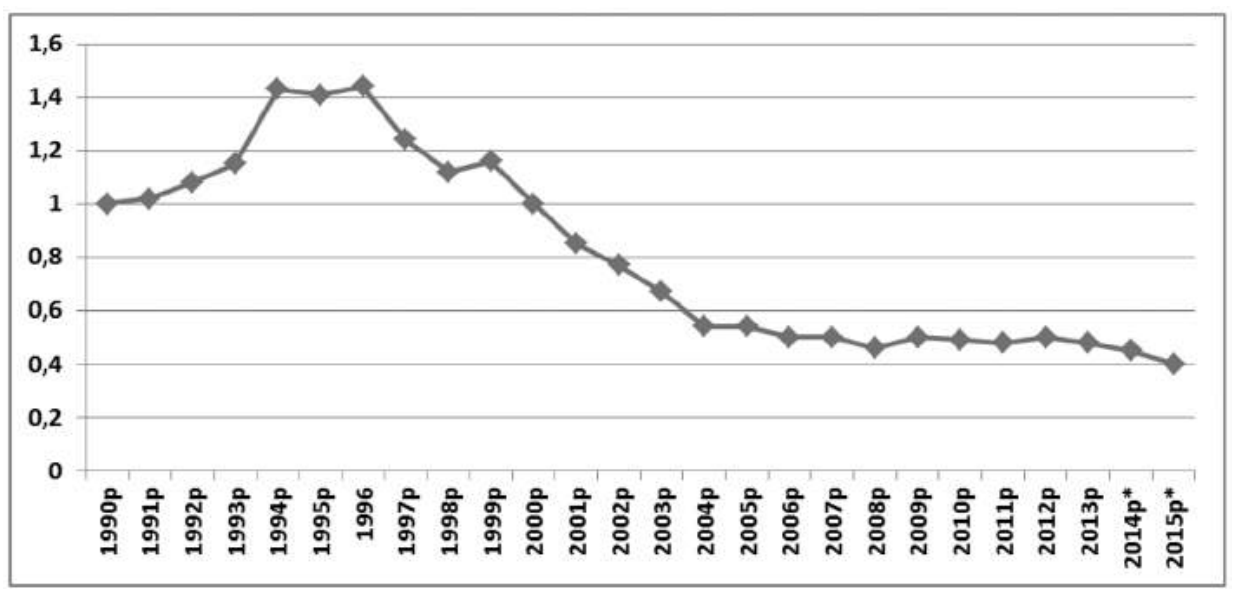

Рисунок 1. Динаміка індексу водоємності ВВП України, $1990-2015$ pp. $^{2}$

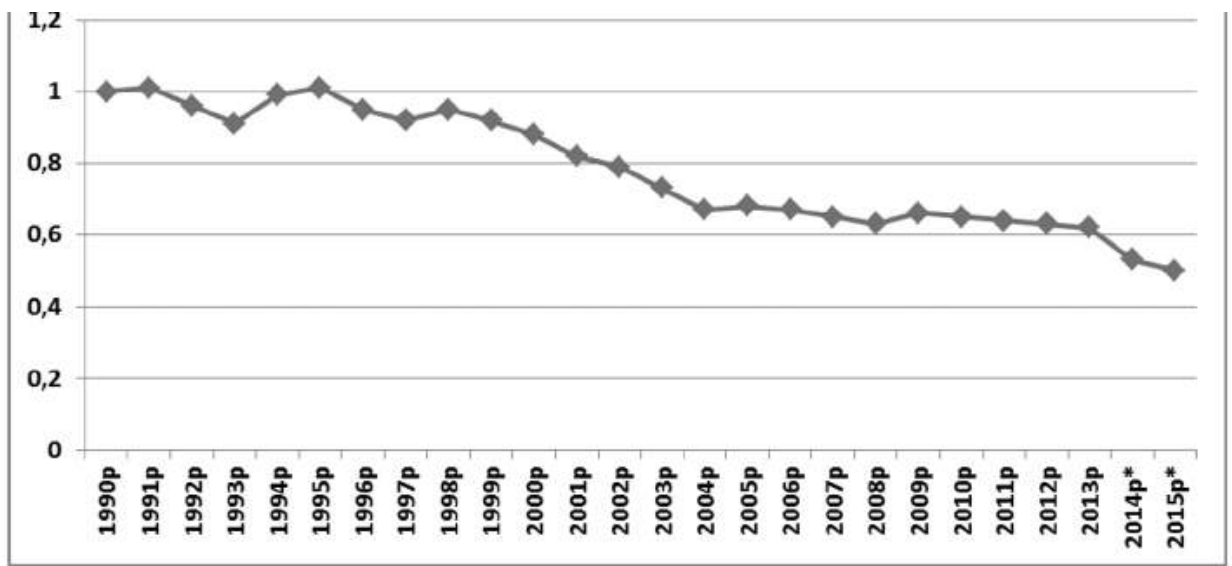

Рисунок 2. Динаміка індексу викидів шкідливих речовин в атмосферне повітря на одиницю ВВП України, 1990 -2015 pp. $^{2}$

зокрема і в галузі природокористування, охорони навколишнього природного середовища. Це завдання значною мірою виконане. Нині в країні діє 200 відповідних законодавчих актів. Крім того, Україна підписала значну кількість міжнародних документів, що регулюють питання використання і охорони природних ресурсів, переходу до сталого (збалансованого) розвитку, активно співпрацює в цій сфері з ООН, є стороною понад 40 глобальних та регіональних природоохоронних конвенцій та угод. На жаль, положення багатьох прийнятих документів досі не реалізовані, а питома природоємність української економіки залишається високою.

Водночас за всі роки незалежності в економіці країни не відбулося якісних змін в інноваційному оновленні та здійсненні принципової структурної перебудови, яка б могла забезпечити належний рівень конкурентоспроможності, економічної ефективності, зменшила б рівень природоємності виробництва та забезпечила реальний перехід до сталої моделі розвитку національної економіки.

Підтвердженням цього може бути динаміка індексу водосмності ВВП Украӥни (рис. 1.)

Як видно 3 даних рисунка 1, за період після саміту в Йоганнесбурзі водоємність ВВП країни зменшилася трохи більше, ніж на третину. При цьому в період 2004-2011 рр. величина індексу водоємності практично не змінювалася. Але загальний рівень водоємності ВВП України 2014 p. більше ніж у 2 рази перевищував середньосвітовий рівень. Це свідчить про відсутність позитивних зрушень щодо використання водних ресурсів на засадах впровадження моделі сталого водоспоживання.

Подібна динаміка спостерігається і щодо індексу викидів шкідливих забруднюючих речовин у атмосферне повітря (рис. 2).

Як видно з рисунка 2, за період 3 часу незалежності України, індекс викидів шкідливих речовин в атмосферу на одиницю ВВП в Україні істотно не зменшився. Незважаючи на певне зниження питомих обсягів використання ресурсів при виробництві одиниці ВВП, економіка України залишається однією 3 найбільш природоємних у світі (рис. 3). Понад 2/3 загального обсягу реалізованої промислової продукції припадає на галузі, що виробляють сировину, матеріали та енергетичні ресурси. Гіпертрофована енергосировинна спрямованість промислового виробництва сформувалася під визначальним впливом зовнішнього фактора - сприятливої світової кон'юнктури на базові низькотехнологічні сировинні категорії товарного експорту. Така

${ }^{2}$ Без урахування тимчасово окупованої території Автономної Республіки Крим, м. Севастополь та частини зони проведення антитерористичної операції. 


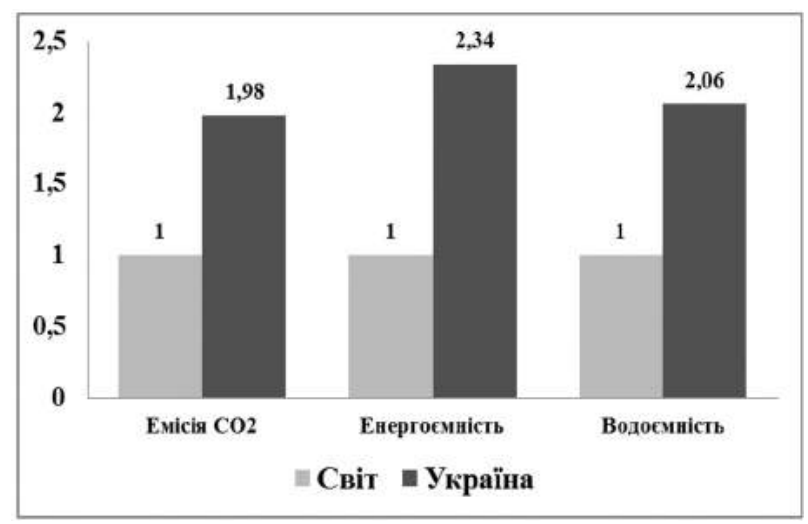

Рисунок 3. Україна і світ. Співвідношення індексів природоємності, 2013 р.

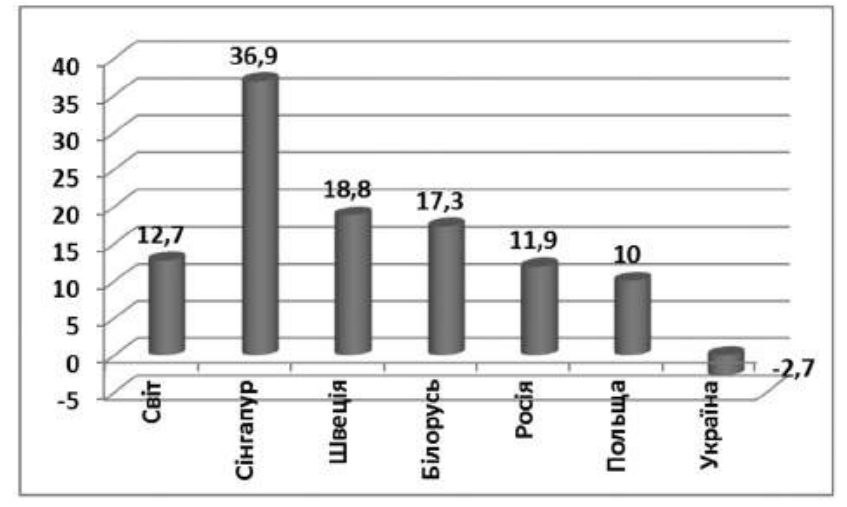

Рисунок 4. Україна, окремі країни світу. Показник адаптованих чистих заощаджень, 2014 p. ${ }^{3}$

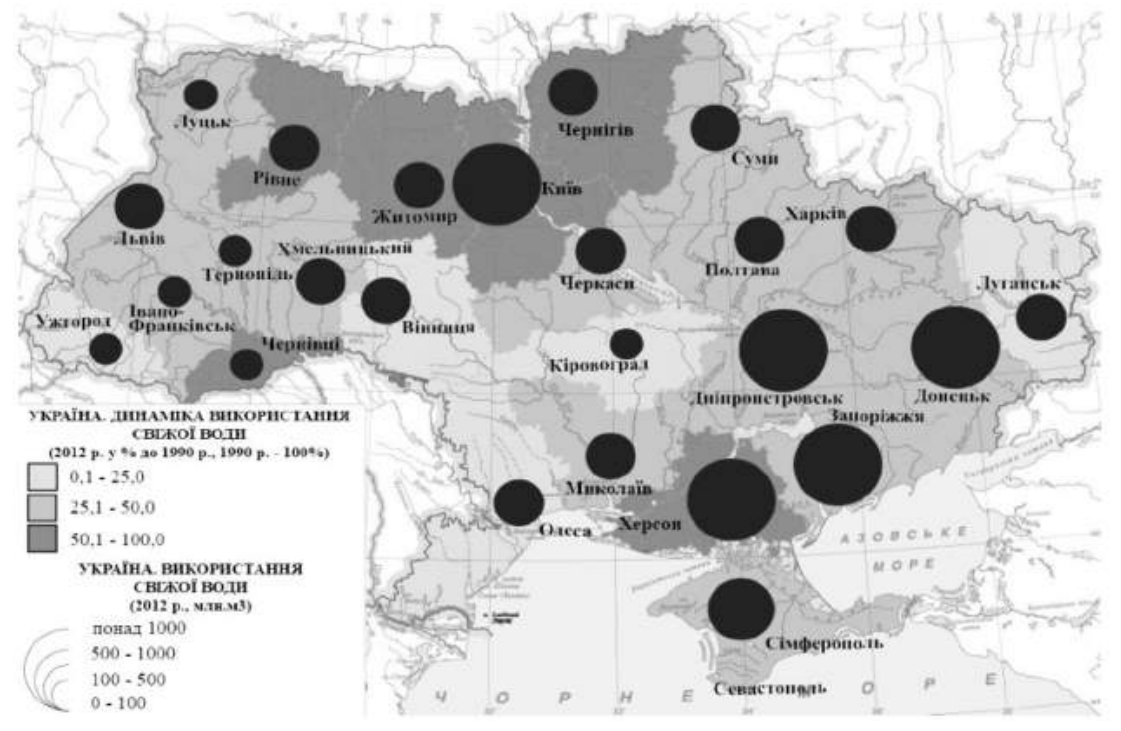

Рисунок 5. Україна. Динаміка використання свіжої води за регіонами, 1990-2012 pp.

Укладено за даними Державної служби статистики України

свідчать, що ефективність природокористування в Україні поступається навіть російській, хоч РФ має надзвичайно виражений сировинний характер економіки, однак використовує свої ресурси ефективніше.

3 початку 90 -х років відбулися значні зрушення в показниках, що відображають територіальні аспекти природокористування в Україні та антропогенний вплив на навколишне природне середовище. Вони зумовлені різними темпами розвитку регіонів, змінами в структурі регіональних економік, рівнем технологій тощо.

Як свідчать дані (рис. 5), внаслідок спаду виробництва в Україні загалом та у регіонах водоспоживання зменшилось майже втричі; найбільше у Вінницькій (до $6,1 \%$ від рівня

ситуація законсервувала неефективну структурну деформацію промисловості без відповідної уваги до переробних галузей. Неефективна бюджетна підтримка високотехнологічних галузей промисловості призвела до зменшення у структурі випуску частки видів промислової діяльності, орієнтованих на внутрішній ринок. Іншою важливою тенденцією стали низькі темпи модернізації виробництва. На відміну від розвинених країн світу, промисловість України базується переважно на традиційних технологіях, започаткованих на ранніх стадіях індустріалізації [8].

Показником, який найкраще відображає наслідки низької еколого-економічної ефективності природокористування в Україні, можна вважати показник адаптованих чистих заощаджень. Цей індикатор показує наскільки ефективно використовуються природні ресурси для забезпечення економічного розвитку.

Україна в 2014 р. відносилася до 8 країн світу 3 від'ємним значенням цього показника (рис.4.) Дані
1990 р.), Луганській $(14,85)$, Кіровоградській $(18,5)$, Закарпатській $(20,8)$, Одеській $(22,8)$ областях. Водночас збереглась диспропорція між рівнями водозабезпеченості та водоспоживання - найбільші абсолютні обсяги спостерігались у Дніпропетровській, Донецькій, Запорізькій і Херсонській областях.

Споживання води у великих містах України за десять років (2000 - 2010) значно скоротилося (за винятком міст Севастополь, Чернігів і Слов'янськ). Найбільше скорочення спостерігалось в промислових містах (Сєверодонецьк, Лисичанськ, Алчевськ, Нікополь, Краматорськ та ін.) та у містах 3 населенням понад 500 тис. осіб (Дніпропетровськ, Одеса, Київ, Харків та ін.), що спричинено занепадом водоємних виробництв. Недивлячись на те, що використання води у великих містах суттєво скоротилося (з 5650 млн. м ${ }^{3}$ до 4315 млн м³), їх частка у загальноукраїнському споживанні зросла з $43 \%$ до

${ }^{3}$ The World Bank. http://data.worldbank.org/ 


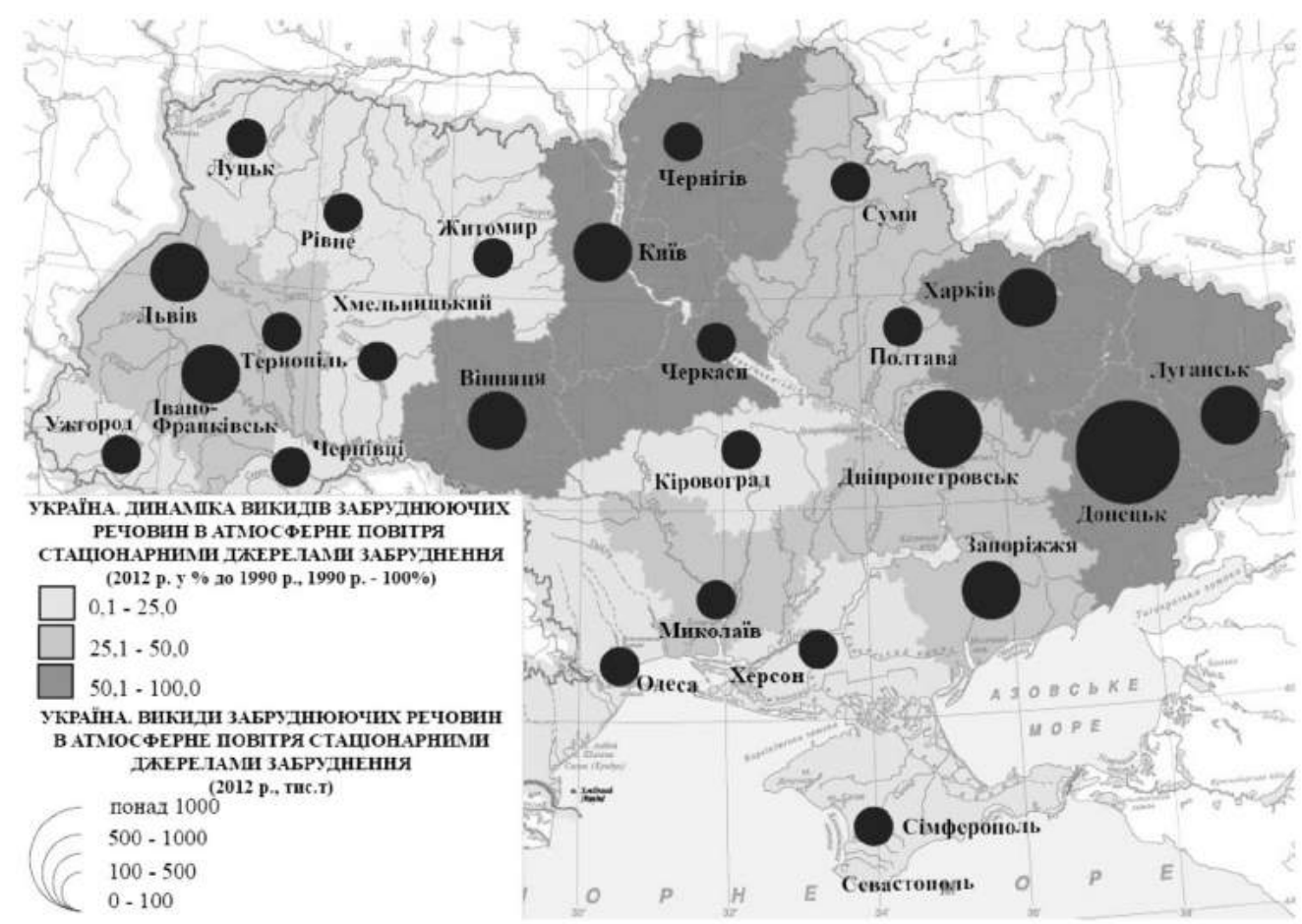

Рисунок 6. Україна. Динаміка викидів забруднюючих речовин в атмосферу стаціонарними джерелами, 1990-2012 pp.

Укладено за даними Державної служби статистики України

$45 \%$. Це означає, що скорочення споживання води в інших типах поселень відбувається швидшими темпами. Основними споживачами в 2010 р. були Маріуполь, Донецьк та Київ (25\% від загальноукраїнського споживання води).

Порівняно з 1990 р. значно скоротились викиди шкідливих речовин в атмосферу стаціонарними джерелами забруднення (рис. 6).

Скорочення кількості викидів в атмосферу більше ніж удвічі відбулося переважно внаслідок економічної кризи в першій половині $90-x$ років і мало місце в усіх регіонах країни, особливо - в Кіровоградській, Херсонській, Чернівецькій областях. Меншою мірою це стосувалось регіонів, які були головними забруднювачами атмосфери в 1990 р.

Основними забруднювачами в Україні і надалі залишались Донецька, Дніпропетровська, Луганська та Запорізька області, частка яких за останні десять років скоротилася лише із $76 \%$ до $72 \%{ }^{4}$.

У великих містах викиди забруднюючих речовин від стаціонарних джерел у 2010 р. скоротилися (1535,2 тис. т) порівняно 32000 р. (1953 тис. т), на відміну від загальної ситуації в Україні, де кількість викидів зросла. У процентному співвідношенні частка великих міст у загальноукраїнських викидах скоротилася з 49\% до $31 \%$. Серед великих міст основними забруднювачами (понад $1 \%$ ) ста-

43 часу агресії Росії на Донбасі точні дані щодо частини районів регіону відсутні. ном на 2010 р. були: Дніпропетровськ, Дніпродзержинськ, Кривий Ріг, Донецьк, Макіївка, Маріуполь, Запоріжжя, Луганськ та Алчевськ. Сумарний еквівалент цих дев'яти міст фактично склав $1 / 3$ усіх викидів по Україні. Варто зауважити, що понад 7\% від загальноукраїнських викидів припадає на Кривий Ріг.

За окремими видами економічної діяльності в 2015 р. максимальні обсяги викидів припадали на постачання електроенергії, газу, пари та кондиційованого повітря (енергетика), металургійне виробництво, добувну промисловість (рис. 7).

Щодо добувної промисловості, порівняно 3 1990 р. обсяги видобутку багатьох корисних копалин значно скоротились. Однак станом на 2013 р. у значних обсягах видобували: кам'яне вугілля $(1,5 \%$ світового видобутку), товарні залізні $(4,5 \%)$ та марганцеві (9\%) руди, уран, титан, цирконій, каолін (19\%), бром, нерудну металургійну сировину (кварцити, флюсові вапняки і доломіти), хімічну сировину (кам'яна сіль), облицювальний камінь (граніт, габро, лабрадорит тощо), скляний пісок та окремі інші види корисних копалин.

3 початку 90x рр. скоротилася кількість викидів від пересувних джерел забруднення, де головну роль відіграє автотранспорт (рис. 8). У структурі викидів автотранспорту понад $2 / 3$ припадає на автотранспорт населення, відповідно найбільші їх обсяги (майже 50\%) припадають на великі міста: 

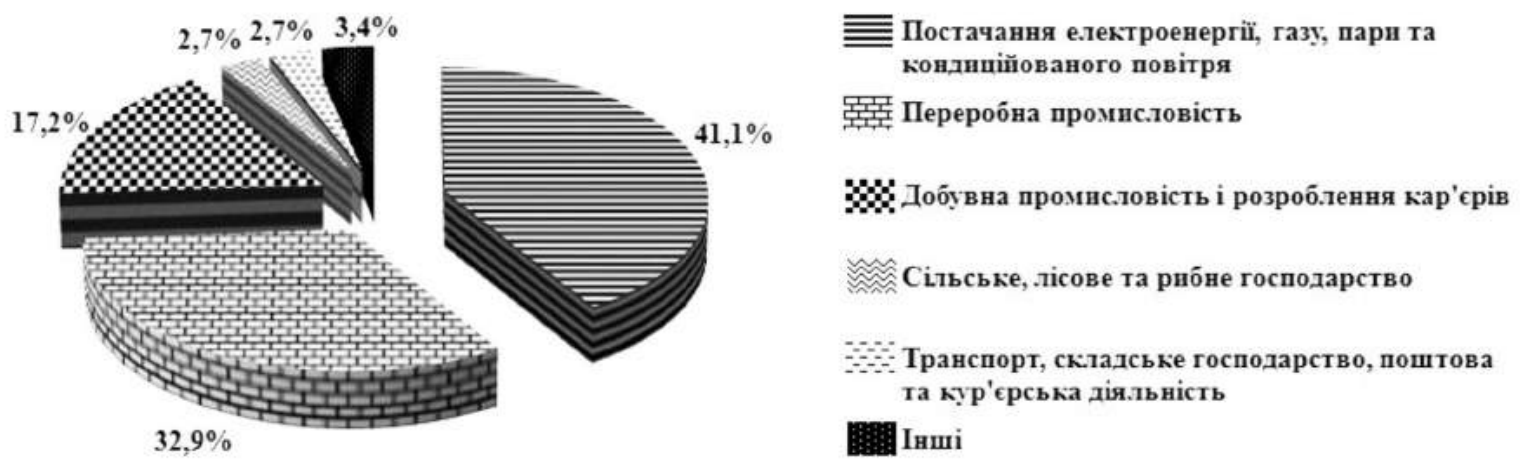

Рисунок 7. Викиди забруднюючих речовин у атмосферу по Україні за видами економічної діяльності y 2015 p.

Укладено за даними Державної служби статистики України

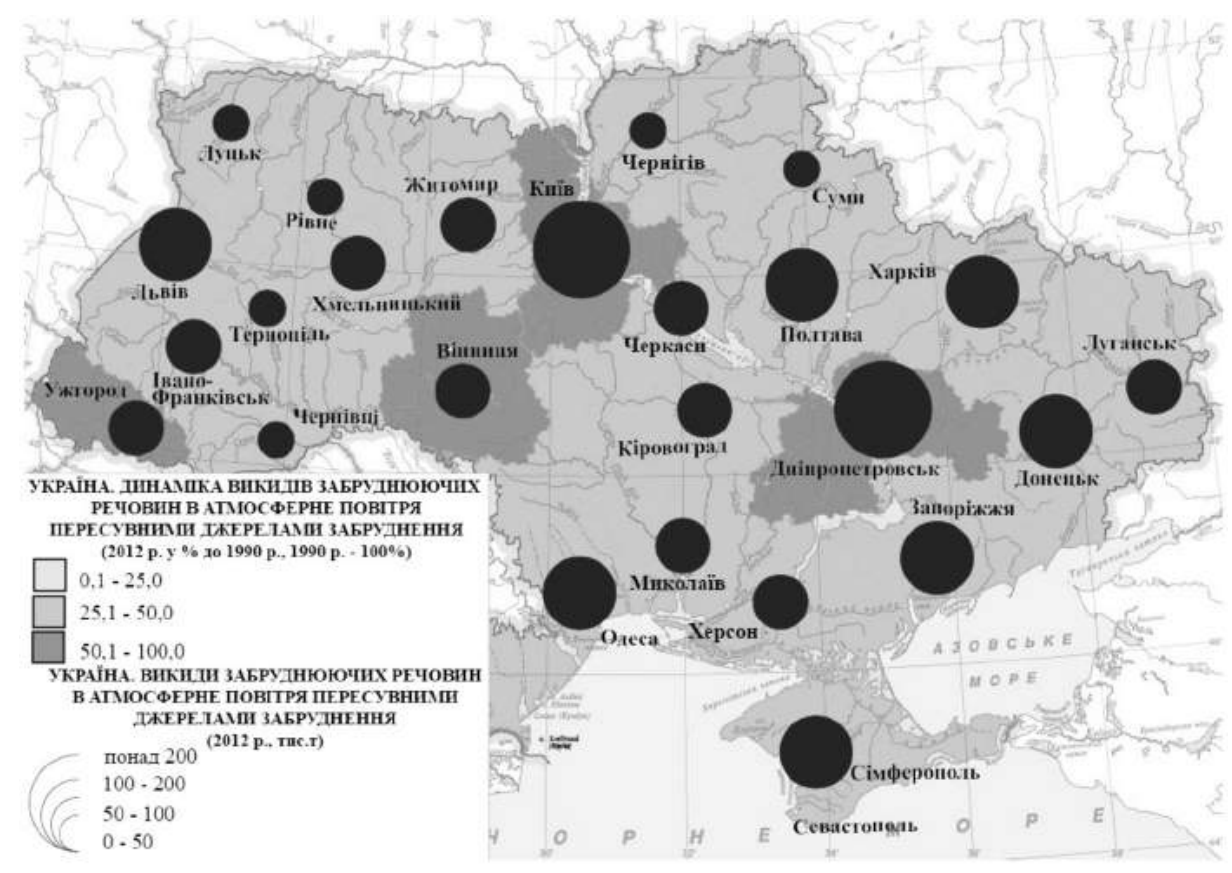

Рисунок 8. Україна. Динаміка викидів забруднюючих речовин пересувними джерелами в атмосферу, 1990-2012 pp.

Укладено за даними Державної служби статистики України

Київ, Харків, Одесу, Дніпропетровськ, Донецьк, Кривий Ріг, Запоріжжя, Львів, Миколаїв, Сімферополь та Маріуполь, серед них найбільше - на Київ.

Слід зазначити, що частка великих міст скоротилася з 48\% (2000 р.) до 44\% (2010 р.), але в абсолютних одиницях кількість викидів зросла майже на 100 тис. т.

Такі тенденції спричинені збільшенням викидів від транспортних джерел в інших населених пунктах, зокрема у більшості міст 3 населенням понад 500 тис. осіб, за винятком Запоріжжя (одночасно 3 підвищенням купівельної спроможності насе-

\footnotetext{
${ }^{5}$ Без даних про тимчасово окуповані АР Крим та місто Севастополь. Дані по Донецькій і Луганській областях можуть бути уточнені.
}

лення). Менше скорочення викидів простежується в східних областях, що зумовлено промисловою функцією міст та використанням потужної транспортної бази.

Значною проблемою в Україні залишається велика кількість відходів, динаміку утворення яких за видами економічної діяльності дано в таблиці 1. 3 урахуванням динаміки ВВП України можна зазначити, що рівень утворення відходів надмірно зріс - 3 675,1 кг / 1000 дол. США в 1995 р. до 1004,2 кг / 1000 дол. США в 2015 р.

Окремим питанням $є$ особливості змін у сільськогосподарському природокористуванні, використання земельних ресурсів загалом. За ефектив- 
Таблиця 1.Утворення відходів в Україні, 1995 -2015 pp. ${ }^{6}$

\begin{tabular}{|l|c|c|c|c|c|}
\hline \multicolumn{1}{|c|}{ Утворено відходів, 1000 т/рік } & 1995 & 2000 & 2005 & 2010 & 2015 \\
\hline \multicolumn{1}{|c|}{ Усього } & 176400,2 & 184192,4 & 231189,5 & 425914,2 & 312267,6 \\
\hline $\begin{array}{l}\text { Сільське, лісове та рибне } \\
\text { господарство }\end{array}$ & 642,2 & 1251,3 & 2593,0 & 8568,2 & 8736,8 \\
\hline $\begin{array}{l}\text { Добувна промисловість і } \\
\text { розроблення кар'єрів }\end{array}$ & $\ldots$ & $\ldots$ & 161817,6 & 321889,8 & 232642,4 \\
\hline Переробна промисловість & $\ldots$ & $\ldots$ & 54800,8 & 75950,4 & 56506,3 \\
\hline $\begin{array}{l}\text { Постачання електроенергії, газу, } \\
\text { пари та кондиційованого повітря }\end{array}$ & 12817,7 & 10066,1 & 8104,7 & 8641,0 & 6597,5 \\
\hline Будівництво & 54,8 & 19,1 & 198,7 & 189,0 & 89,9 \\
\hline Інші види економічної діяльності & 28925,4 & 1025,6 & 3674,7 & 3953,4 & 1047,2 \\
\hline Домогосподарства & $\ldots$ & $\ldots$ & $\ldots$ & 6722,4 & 6053,3 \\
\hline
\end{tabular}

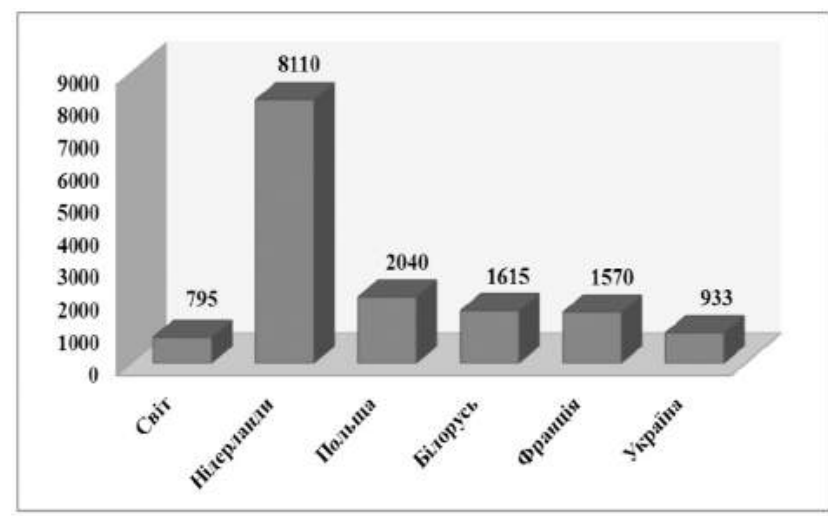

Рисунок 9. Світ, окремі країни. Виробництво сільськогосподарської продукції на одиницю сільськогосподарських земель, дол./га, 2014 р. ${ }^{7,8,9}$

ністю використання сільськогосподарських земель Україна значно поступається багатьом країнам світу, в тому числі найближчим сусідам 3 гіршими природними передумовами ведення сільського господарства (рис. 9).

Після 1990 р. розвиток сільського господарства України відбувався в умовах трансформаційних перетворень економіки, які супроводжувались кризовими явищами і спадом виробництва основних видів сільгосппродукції.

\footnotetext{
${ }^{6}$ Статистичний збірник Довкілля України за 2014 рік.

${ }^{7}$ Central Intelligence Agency. https://www.cia.gov/library/ publications/the-world-factbook/

8 The World Bank. http://data.worldbank.org/indicator/ NY.ADJ.SVNG.GN.ZS

9 The World Bank. http://data.worldbank.org/indicator/ AG.LND.AGRI.ZS
}

На ситуацію в агросекторі держави значно впливали і внутрішні, і зовнішні причини. На думку експертів, основними внутрішніми причинами низької економічної ефективності виробництва продукції АПК України у період переходу до ринкових засад функціонування і розвитку стали: висока собівартість виробництва сільгосппродукції; недостатня конкурентоспроможність вітчизняних племінних (генетичних) ресурсів; недостатній рівень розвитку об'єктів транспортно - логістичної та фінансово - кредитної інфраструктури аграрного ринку і недосконалість каналів та умов просування сільгосппродукції на світові продовольчі ринки; відсутність пріоритетності державної підтримки розвитку агросектора України і національної політики довгострокового закріплення на світових аграрних ринках тощо [5].

Поступово пріоритетом сільського господарства ставало виробництво високоприбуткових, однак грунтовиснажливих технічних (соняшник, ріпак, соя) і зернових (кукурудза) культур. Значному збільшенню обсягів виробництва цих культур сприяли наявність родючих земель, позитивна кон'юнктура світових продовольчих ринків у сукупності з агрогеографічним положенням регіонів України по відношенню до основних ринків збуту, лібералізацією зовнішньої торгівлі внаслідок вступу держави до СОТ та зняттям країною обмежень на експорт зерна у $2010 \mathrm{p}$.

Порівняно з 1990 р. валовий збір соняшнику зріс майже у 4 рази (на 7,5 млн т), кукурудзи - 6,1 разів (23,8 млн т), ріпаку - у 17 разів $(2,1$ млн т), сої - приблизно у 40 разів (3,8 млн т). В 2014 р. приріст їх виробництва становив відповідно 2; 4; 7,5 і 24 млн т.

Зростання валового збору цих культур має 


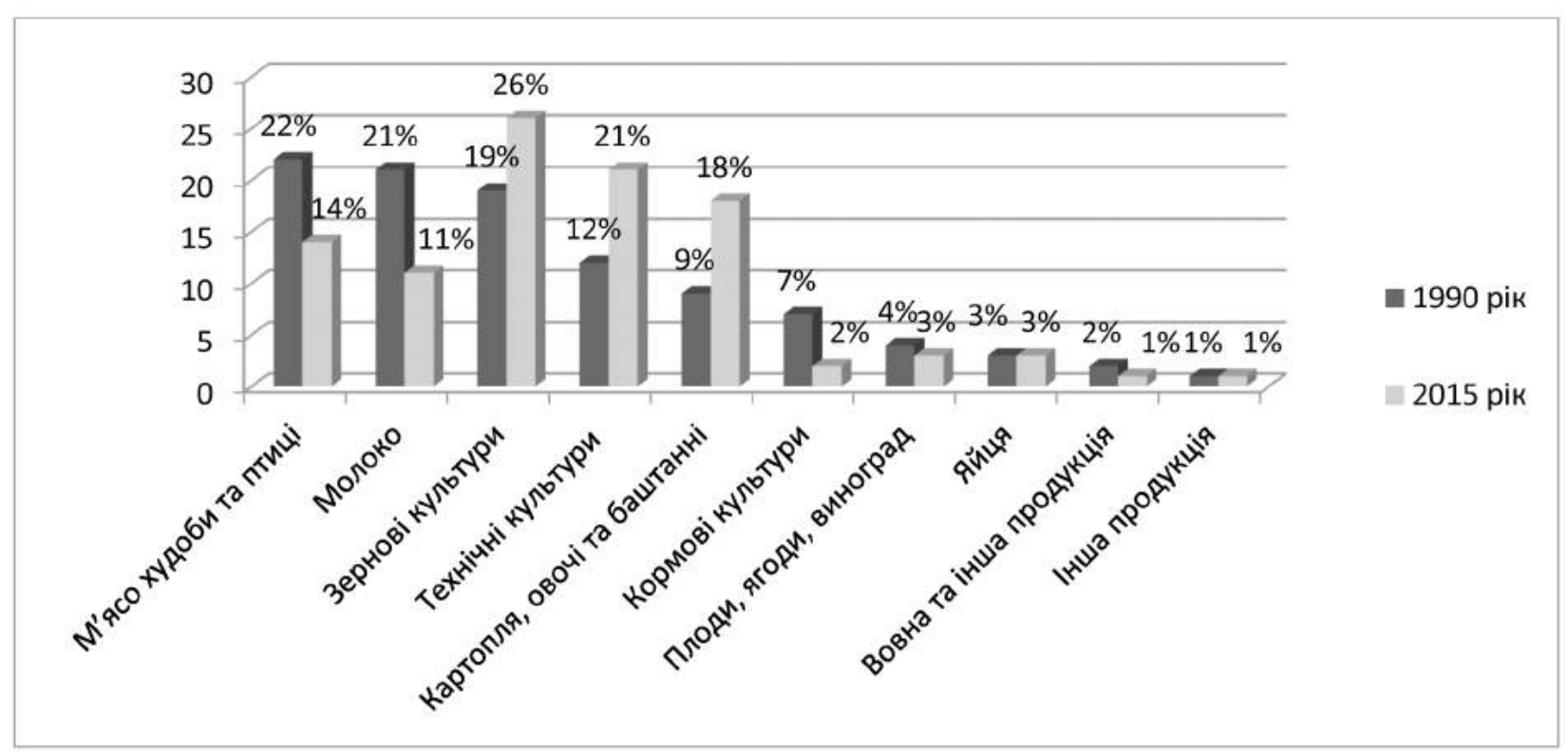

Рисунок 10. Зміни структури виробництва сільгосппродукції у 1990 та 2015 pp., \%

регіональні особливості (1990-2010рр.). Так, збільшення валового збору соняшнику в Україні відбувалось передусім у східних, центральних і південних регіонах (в 2,5-5 разів), ріпаку і сої на Поділлі, у західних, північних, центральних i південних областях (відповідно у 6-1218 разів та 19-1300 разів ). Крім того, значно збільшився валовий збір соняшнику в північних областях і на Хмельниччині. Зокрема, виробництво цієї культури на Сумщині збільшилося у 16 разів, Київщині - 54 рази, Чернігівщині - 137 разів, Хмельниччині - більше ніж у 200 разів, Житомирщині - у понад 840 разів. Обсяги валового збору ріпаку та сої зросли також у центральних (Черкаській, Кіровоградській і Полтавській) та західних (Львівській, Івано-Франківській, Чернівецькій, Рівненській та Волинській) областях.

Збільшення валового збору експортоорієнтованих високорентабельних культур i зменшення обсягів виробництва продукції тваринництва протягом 1990-2015 р. призвели до диспропорцій у структурі валового виробництва сільськогосподарської продукції (рис.10).

Зростання виробництва експортоорієнтованих культур відбулося в основному при збереженні екстенсивного ведення землеробства, без врахування екологічних аспектів розвитку і функціонування найважливішого природного багатства держави - iї грунтів, зокрема чорноземів. Протягом останніх 25 років посіви технічних (соняшник, ріпак та соя) і зернових (кукурудза) культур збільшилися майже на 4,5 і 3 млн га (більш як у 2 i 3 рази). При цьому значно зменшилися посіви цукрових буряків та зернобобових культур (табл. 2).

Необгрунтоване збільшення посівів технічних культур (крім цукрового буряка) і кукурудзи, недос- татні обсяги внесених органічних добрив загалом та на 1 га посівів сільгоспкультур у сукупності 3 надмірним рівнем розораності території країни i високою часткою ріллі у структурі сільгоспугідь зумовлюють процеси інтенсивної деградації й виснаження земельних ресурсів. Найпоширеніший вид деградації, дегуміфікація, охопила $43 \%$ загальної площі сільгоспугідь країни ${ }^{10}$. За результатами агрохімічної паспортизації сільськогосподарських земель протягом 1986-2010 pр. вміст гумусу в грунтах скоротився на $0,22 \%$. Також відбувається збіднення грунтів на вміст таких важливих поживних речовин як рухомий фосфор і калій. Виникла реальна загроза подальшої інтенсивної деградації грунтового покриву та формування малопродуктивних земель [6].

Запобігання розвитку деградаційних процесів, відтворення й підвищення родючості грунтів $\epsilon$ важливими чинниками переходу сільського господарства на засади сталого розвитку, підвищення конкурентоспроможності сільськогосподарського виробництва, а також гарантування екологічної і продовольчої безпеки країни.

\section{Висновки}

Трансформація національної економіки, що іï разом з іншими державами Центральної та Східної Європи розпочала на межі 90-х рр. минулого століття Україна, виявилася для неї набагато складнішим та болючішим процесом, ніж це уявлялося на початку перехідного періоду.

У структурі виробництва збільшилась частка ресурсоємних галузей, що призвело до відповідних

10 За даними ННЦ «Інститут грунтознавства та агрохімії ім. О.Н. Соколовського». 
Таблиця 2. Україна. Динаміка структури посівів основних сільськогосподарських культур, 1990-2015 рр., тис. га

\begin{tabular}{|c|c|c|c|c|c|c|c|c|c|c|}
\hline \multirow[t]{2}{*}{ Посівні площі } & \multirow[t]{2}{*}{1990} & \multirow[t]{2}{*}{2000} & \multirow[t]{2}{*}{2010} & \multirow[t]{2}{*}{2015} & \multicolumn{2}{|c|}{$\begin{array}{c}\text { Збільшення } \\
\text { (зменшення) }\end{array}$} & \multicolumn{2}{|c|}{$\begin{array}{c}\text { Частка у } \\
\text { структурі } \\
\text { посівів, \% }\end{array}$} & \multicolumn{2}{|c|}{$\begin{array}{c}\text { Частка в } \\
\text { загальній } \\
\text { посівній площі, \% }\end{array}$} \\
\hline & & & & & тис. га & разів & 1990 & 2015 & 1990 & 2015 \\
\hline $\begin{array}{c}\text { Вся посівна } \\
\text { площа }\end{array}$ & 32406 & 27173 & 26952 & 26717 & -5148 & 1,2 & - & - & 100 & 100 \\
\hline $\begin{array}{c}\text { Технічні } \\
\text { культури }\end{array}$ & 3751 & 4187 & 7296 & 8210 & 4459 & 2,2 & 100 & 100 & 11,6 & 30,7 \\
\hline \multicolumn{11}{|l|}{ в тому числі } \\
\hline цукровий буряк & 1607 & 856 & 501 & 239 & -1368 & $-6,7$ & 42,8 & 2,9 & 5 & 0,9 \\
\hline соняшник & 1636 & 2943 & 4572 & 4965 & 3329 & 3 & 43,6 & 60,5 & 5,1 & 18,6 \\
\hline соя & 93 & 65 & 1076 & 2147 & 2054 & 23,1 & 2,5 & 26,2 & 0,3 & 8 \\
\hline ріпак & 90 & 214 & 907 & 684 & 594 & 7,6 & 2,4 & 8,3 & 0,3 & 2,6 \\
\hline $\begin{array}{l}\text { Зернові та } \\
\text { зернобобові }\end{array}$ & 14583 & 13646 & 15090 & 14728 & 145 & 1,01 & 100 & 100 & 45,0 & 55,1 \\
\hline \multicolumn{11}{|l|}{ в тому числі } \\
\hline кукурудза & 1234 & 1364 & 2709 & 4137 & 2903 & 3,4 & 8,4 & 28,1 & 3,8 & 15,5 \\
\hline $\begin{array}{l}\text { зернобобові } \\
\text { культури }\end{array}$ & 1424 & 408 & 429 & 251 & -1173 & $-5,7$ & 9,7 & 1,7 & 4,4 & 0,9 \\
\hline $\begin{array}{c}\text { Кормові } \\
\text { культури }\end{array}$ & 11999 & 7063 & 2599 & 1965 & -10034 & $-6,1$ & 100 & 100 & 37 & 7,4 \\
\hline
\end{tabular}

Укладено за даними Державної служби статистики України

змін характеру природокористування в країні. Системним підтвердженням негативних тенденцій в природокористуванні є одне 3 найгірших у світі значення показника адаптованих чистих заощаджень. Низька ефективність використання ресурсів $\epsilon$ однією 3 причин того, що за останні 25 років Україна мала найгірші серед країн світу показники динаміки ВВП. Хоча, як показав проведений аналіз, 3 часу проголошення незалежності показники питомої ресурсоємності України зменшилися (зокрема, показники водоємності та шкідливості для атмосфери - приблизно вдвічі), вони і досі перевищують середньосвітові (питомі викиди, енергоємність, водоємність ВВВ більше ніж у 2 рази).

I це ще раз підкреслює нагальну потребу впровадження «зелених» технологій, переходу до ширшого використання альтернативних джерел енергії, зміни моделей виробництва та споживання.

У сільському господарстві також збереглась деформована структура земельного фонду. Надмірно високою є частка сільськогосподарських угідь із екстремальними значеннями частки ріллі. Спостерігаються негативні тенденції змін в сільськогосподарському виробництві. Зокрема в структурі посівів відбулося стрімке збільшення частки грунтовиснажливих культур. Перехід до багатоукладності призвів до концентрації значних земельних масивів в агрохолдингах, що спеціалізуються переважно на вирощуванні монокультур з метою їх подальшого експорту. Це призвело до порушення пропорцій між рослинництвом і тваринництвом, стрімкого зменшення поголів'я сільськогосподарських тварин, дефіциту органічних добрив тощо. В результаті, за ефективністю використання сільськогосподарських земель Україна значно поступається багатьом країнам світу, в тому числі - найближчим сусідам 3 гіршими природними умовами ведення сільського господарства.

Отже, негативні тенденції в природокористуванні держави зумовлені низкою об'єктивних і суб'єктивних причин зовнішнього і внутрішнього характеру. Серед них - труднощі інтеграції до глобалізованої світової економіки, проблеми подолання трансформаційного періоду тощо. Водночас, головною причиною ситуації, що склалася, можна вважати кризу менеджменту, відсутності у правлячих «еліт» державницької позиції, стратегічного бачення цілей і орієнтирів розвитку країни та бажання захищати державні, а не приватні інтереси.

Важелі для коригування ситуації, що склалася, Україна заклала, взявши на себе зобов'язання, що містяться в міжнародних документах, визначають завдання переходу до сталого (збалансованого) розвитку. Саме виконання зобов'язань щодо змен- 
шення природоємності, енергоємності економіки, збільшення частки відновлюваних джерел в загальному енергоспоживанні, розширення територій 3 природно-заповідним режимом, впровадження сталих моделей виробництва і споживання, переходу до низьковуглецевої економіки, збереження біорізноманіття, боротьби 3 опустелюванням та змінами клімату тощо $є$ одним із важливих чинників, які можуть оптимізувати стан природокористування в країні.
Для практичного впровадження цього в Україні має бути затверджена Стратегія сталого (збалансованого) розвитку, яку слід, як і в інших країнах світу, що здійснили реальні кроки до оптимізації природокористування та переходу до сталого розвитку, періодично оновлювати та моніторити. Дорожньою картою 3 виконання завдань Стратегії мають бути відповідні Національні плани дій та індикатори, що містяться у 17 глобальних цілях сталого розвитку ООН.

\section{References [Лimepamypa]}

1. Geographical science at the National Academy of Sciences of Ukraine / ed. by academician L.H. Rudenko (2009). Kyiv. [In Ukrainian].

[Географічна наука в Національній академії наук України / за ред. академіка Л.Г. Руденка. - К., 2009. - 240 с.]

2. Rudenko L.H., Parkhomenko H.O., Molochko A.N. et al. (1991). Cartographic research of nature use. Kyiv: Naukova dumka. [In Russian].

[Картографические исследования природопользования / Л.Г. Руденко, Г.О. Пархоменко, А.Н. Молочко и др. - К.: Наук. думка, 1991. - 212 с.]

3. Marynych A.M., Palamarchuk M.M., Rudenko L.H. et al. (1988). Constructive-geographical bases of rational nature management in the Ukrainian SSR. Kiev Pridneprovie. Kyiv: Naukova dumka. [In Russian].

[Конструктивно-географические основы рационального природопользования в Украинской ССР. Киевское Приднепровье / А.М.Маринич, М.М.Паламарчук, Л.Г.Руденко и др. - К.: Наук. думка, 1988. - 176 с.]

4. Marynych A.M., Horlenko I.A., Rudenko L.H. et al. Ed. A.M. Marynych, M.M. Palamarchuk. (1990). Constructive-geographical bases of rational nature management in the Ukrainian SSR. Theoretical and methodological research. Kyiv: Naukova dumka. [In Russian].

[Конструктивно-географические основы рационального природопользования в Украинской ССР. Теоретические и методические исследования / А.М.Маринич, И.А.Горленко, Л.Г.Руденко и др. Отв. ред. А.М. Маринич, М.М. Паламарчук. К.: Наук. думка, 1990.- 200 с.]

5. The concept of the state program of development of the agricultural sector for the period until 2020. http://minagro.gov.ua/node/ 16822 [In Ukrainian].

[Концепція державної цільової програми розвитку аграрного сектора економіки на період до 2020 poкy. // http://minagro.gov. ua/node/ 16822]

6. National Report on the State of Environment in Ukraine in 2012. http//www.menr.gov.ua/dopovidi [In Ukrainian].

[Національна доповідь про стан навколишнього природного середовища в Україні у 2012 році. http//www.menr.gov.ua/ dopovidi]

7. Voloshyn V.V., Horlenko I.O., Kukhar V.P., Rudenko L.H., Shevchuk V.Ya. (1995). Approaches to the concept of sustainable development and its integration towards Ukraine. Ukrainian geographical journal, 3, 3-10. [In Ukrainian].

[Підходи до концепції стійкого розвитку та іiі інтеграція стосовно України / В.В. Волошин, І.О. Горленко, В.П. Кухар, Л.Г. Руденко, В.Я. Шевчук // Укр. геогр. журн. - 1995. - № 3. - С. 3-10.]

8. Lisovskyi S.A., Marushevskyi H.B., Pavlychenko P.H., Rudenko L.H., Tymochko T.V. (2012). Project Ukraine report to the UN Conference on sustainable (balanced) development Rio +20 . Kyiv: Center for environmental education and information. [In Ukrainian].

[Проект доповіді України до конференції ООН зі сталого (збалансованого) розвитку Ріо + 20. / С.А. Лісовський, Г.Б. Марушевський, П.Г. Павличенко, Л.Г. Руденко, Т.В. Тимочко. - К.: Центр екологічної освіти та інформації, 2012. - 60 с.]

9. Horlenko I.A., Rudenko L.H., Maliuk S.N., Lebed N.P. (1991). Balanced economic, social and ecological development of the territory (economic and geographical aspects). Kyiv. [In Russian].

[Сбалансированное экономическое, социальное и экологическое развитие территории (экономико-географические аспекты) / И.А.Горленко, Л.Г.Руденко, С.Н.Малюк, Н.П.Лебедь. - К., 1991. - 56 с.]

10. Rudenko L.H. (1998). Sustainable Development: the search for models of sustainable development of Ukraine. Ukrainian geographical journal, 1, 5-12. [In Ukrainian].

[Руденко Л.Г. Сталий розвиток: пошуки моделей сталого розвитку України // Укр. геогр. журн. - 1998. - № 1. - С. 5-12.]

11. Implementation in Ukraine of the provisions of the Agenda for the XXI Century (2002 - 2012). Ed. L.H. Rudenko (2014). Kyiv: Academperiodyca. [In Ukrainian].

[Стан виконання в Україні положень «Порядку денного на XXI століття» (2002 - 2012). / За ред. Л.Г. Руденка. - К.: Академперіодика, 2014. - 359 с.]

12. Ukraine: main trends of interaction between society and nature in the twentieth century (neographical aspect). Ed. L.H. Rudenko. (2005). - Kyiv: Academperiodyca. [In Ukrainian].

[Україна: основні тенденції взаємодії суспільства і природи у ХХ ст. (географічний аспект). За ред. Л.Г. Руденка. - К.: Академперіодика, 2005. - 320 с.] 